\title{
MEMBANGUN BRAND PREFERENCE MELALUI CORPORATE SOCIAL RESPONSIBILITY DAN PERCEIVED BRAND QUALITY
}

\author{
Michael Kanisius $^{1 \#}$ dan Ari Setiyaningrum ${ }^{2 *}$ \\ \# Universitas Katolik Indonesia Atma Jaya \\ Fakultas Ekonomi dan Bisnis \\ Jalan Jenderal Sudirman no. 51 Jakarta \\ E-mail: michaelkanikani@gmail.com \\ *Universitas Katolik Indonesia Atma Jaya \\ Fakultas Ekonomi dan Bisnis \\ Jalan Jenderal Sudirman no. 51 Jakarta \\ E-mail: ari.setiyaningrum@atmajaya.ac.id
}

\begin{abstract}
Abstrak
Penelitian ini bertujuan untuk menganalisis pengaruh Corporate Social Responsibility (CSR) dan perceived brand quality terhadap brand preference pada konteks perusahaan perbankan. CSR yang diteliti mencakup CSR to environment, CSR to society, CSR to stakeholders, dan CSR reputation. BCA dipilih sebagai obyek penelitian dengan pertimbangan BCA merupakan bank swasta terbaik yang aktif menerapkan CSR. Penelitian dilakukan dengan metode survei melalui pendistribusian kuesioner kepada 173 nasabah BCA yang telah mengetahui tentang program-program CSR dari BCA. Metode pengambilan sampel yang digunakan dalam penelitian ini adalah nonprobability sampling dengan teknik purposive sampling dan snowball sampling. Data dianalisis dengan menggunakan analisis regresi linier berganda. Hasil penelitian menemukan bahwa CSR to environment, CSR to society, CSR to stakeholders, CSR reputation, and perceived brand quality berpengaruh terhadap brand preference.
\end{abstract}

Kata kunci: CSR, perceived brand quality, brand preference, banking company

\begin{abstract}
This study aims to analyze the effect of Corporate Social Responsibility (CSR) and perceived brand quality on brand preference in the context of banking company. CSR includes CSR to environment, CSR to society, CSR to stakeholders, and CSR reputation. BCA was chosen as the object of this study with the consideration that BCA is the best private bank that actively implements CSR. This study was conducted by survey method through distributing questionnaires to 173 BCA customers who were aware about BCA's CSR programs. The sampling method used in this study was nonprobability sampling with purposive sampling and snowball sampling techniques. Data was analyzed by multiple linear regression analysis. The findings of the study indicated that CSR to environment, CSR to society, CSR to stakeholders, CSR reputation, and perceived brand quality influenced brand preference.
\end{abstract}

Keywords: CSR, perceived brand quality, brand preference, banking company 


\section{Pendahuluan}

Semakin ketatnya tingkat persaingan yang terjadi di era globalisasi saat ini menuntut perusahaan untuk terus berinovasi dan menyusun berbagai strategi agar dapat mempertahankan pelanggan yang sudah ada dan menarik pelanggan baru. Salah satu strategi yang dapatDilakukan oleh perusahaan adalah dengan menerapkan Corporate Social Responsibility (CSR).

CSR merupakan upaya yang dilakukan perusahaan untuk menyeimbangkan kepentingan bisnis dan kepentingan masyarakat. CSR menggambarkan konsep bahwa perusahaan bisnis memiliki kepentingan yang lebih luas pada masyarakat dan tidak hanya mementingkan kepentingan pribadi perusahaan (Sen Dan Bhattacharya, 2001). Awalnya praktek-praktek CSR yang dilakukan perusahaan bersifat sukarela, namun dengan adanya regulasi dari pemerintah, CSR saat ini merupakan kewajiban yang harus dipenuhi oleh semua perusahaan tanpa terkecuali. Artinya, kesuksesan dan keberlanjutan perusahaan di masa mendatang secara tidak langsung juga dipengaruhi oleh CSR. Bahkan dalam konteks industri yang kontroversial sekalipun seperti industri rokok, CSR juga ditemukan berperan penting pada peningkatan reputasi perusahaan dan kepercayaan pada perusahaan yang dapat memperkuat ikatan konsumen dengan perusahaan (Setiyaningrum dan Aryanto, 2016).

Polonsky dan Jevons (2006) mengemukakan bahwa perusahaan yang paham mengenai bagaimana mengintegrasikan CSR kedalam aktivitas mereknya akan mencapai keunggulan kompetitif melebih pesaing. Karena itu, CSR dapat dijadikan sebagai salah satu strategi bagi perusahaan untuk membangun brand preference. Sejumlah studi terdahulu menemukan bahwa CSR memiliki peran penting pada pembentukan brand preference. Liu et al. (2014) menemukan bahwa CSR yang mencakup CSR to stakeholders, CSR to society, dan CSR to environment berpengaruh positif terhadap brand preference baik secara langsung maupun secara tidak langsung melalui peran mediasi perceived brand quality di industri perhotelan. CSR to stakeholder ditemukan memiliki pengaruh paling kuat terhadap brand preference dibandingkan dengan CSR to society dan CSR to environment. Temuan tersebut didukung oleh Chomvilailuk dan Butcher (2010) yang juga menemukan bahwa CSR initiatives, CSR reputation, dan perceived brand quality berpengaruh positif terhadap brand preference di industri perbankan. Namun demikian, Chomvilailuk dan Butcher (2010) menguji CSR initiatives hanya secara umum tanpa membedakan tipe CSR initiatives. Masing-masing tipe CSR initiatives memiliki karakteristik yang berbeda sehingga pengaruhnya terhadap brand preference juga dapat berbeda.

Penelitian ini bertujuan untuk melengkapi penelitian terdahulu yang dilakukan oleh Chomvilailuk dan Butcher (2010) dengan menguji perceived brand quality, CSR reputation, dan CSR initiatives yang dibedakan menjadi tiga tipe yaitu CSR to stakeholders, CSR to society, dan CSR to environment kemudian menguji pengaruh masing-masing variabel tersebut pada brand preference.

Penelitian ini berfokus untuk meneliti CSR dalam konteks perusahaan perbankan. Bank yang diteliti adalah Bank BCA dengan pertimbangan Bank BCA adalah bank swasta terbaik di Indonesia yang juga aktif menerapkan program CSR. Bank BCA adalah bank swasta terbesar di Indonesia yang berhasil dalam memberikan layanan dan produk perbankan bagi nasabah dan stakeholder's yang memperoleh pengakuan nasional sampai internasional. Pengakuan dari internasional yang diterima Bank BCA salah satunya yaitu sebagai Bank Terbaik oleh Euromoney Awards for Excellence 2018 di Hong Kong dan pengakuan dari kancah nasional yang diterima Bank BCA yaitu Best Bank in Indonesia oleh FinanceAsia (Rahayu, 2018). Penghargaan Euromoney Awards for Excellence merupakan penghargaan bergensi yang diselenggarakan oleh Majalah Euromoney, yang mana Majalah Euromoney adalah media referensi yang telah 50 tahun lebih mengkaji isu finansial 
relevan dari berbagai belahan dunia. Di bidang CSR, program CSR yang dilakukan Bank BCA adalah Bakti BCA yang mencakup Bakti Solusi Cerdas BCA di bidang pendidikan, Solusi Sinergi BCA di bidang budaya, kesehatan, budaya, lingkungan, olah raga maupun empati, dan Solusi Bisnis Unggul (www.bca.co.id, 2019).

\section{Kerangka Teori}

\section{CSR to environment}

Sen Dan Bhattacharya (2001) menjelaskan bahwa salah satu dari enam hal pokok yang termasuk dalam CSR yaitu environment. Environment yang dimaksud dalam konteks CSR yaitu menciptakan lingkungan yang sehat dan aman, mengolah limbah dengan bijaksana, dan memproduksi produk-produk yang ramah lingkungan. CSR to environment menggambarkan aktivitas tanggung jawab sosial perusahaan yang diarahkan pada upaya untuk melestarikan lingkungan. Upaya-upaya tersebut mencakup perusahaan menggunakan produk daur ulang, menghemat air dan listrik yang mana dapat menurunkan biaya operasi sehingga dapat meningkatkan pendapatan. Upaya selanjutnya seperti menciptakan lingkungan yang sehat serta mengolah limbah dengan bijaksana yang mana harus mengurangi dampak buruk ke lingkungan sekitar. Perusahaan di industri perbankan yang melakukan tanggung jawab sosial pada lingkungan seperti ajakan untuk menanam seribu pohon, menghemat penggunaan listrik dan air Akan memiliki daya tarik lebih terhadap nasabahnya dan dapat menjadi suatu keunggulan kompetitif bagi perusahaan itu sendiri.

\section{CSR to society}

CSR menggambarkan tanggung jawab perusahaan untuk memaksimalkan dampak positif dan meminimalkan dampak negatif pada masyarakat dengan melakukan hal-hal yang melampaui kebaikan dalam etika bisnis yang merepresentasikan moral dari perusahaan yang melakukan (Sen Dan Bhattacharya, 2001). CSR to society menggambarkan aktivitas tanggung jawab sosial perusahaan yang diarahkan pada upaya untuk meningkatkan kesejahteraan masyarakat seperti menyalurkan Dana kepada masyarakat yang membutuhkan, membantu pembangunan infrastruktur yang sedang dilakukan di lingkungan perusahaan serta ikut membantu anak yatim piatu yang membutuhkan bantuan sosial. Upaya yang juga penting yakni selalu berusaha untuk mengurangi dampak negatif yang timbul serta memaksimalkan dampak positif jangka panjang untuk masyarakat sekitar. Dalam konteks perusahaan perbankan, CSR to society dapat dilakukan dengan Cara mengajak masyarakat untuk menabung untuk hari tua, memberikan bantuan kepada korban bencana alam serta membantu mengembangkan keterampilan kreatif untuk masyarakat.

\section{CSR to stakeholders}

Sen et al. (2006) menekankan bahwa stakeholders' Akan memberikan reaksi yang positif pada perusahaan yang menerapkan CSR. Konsumen selaku salah satu stakeholder Akan memberikan reaksi positif dalam bentuk kesediaan untuk membeli produk-produk yang ditawarkan perusahaan. Investor memberikan reaksi positif dalam bentuk investasi pada perusahaan yang aktif menerapkan CSR. CSR to stakeholders' menggambarkan aktivitas tanggung jawab sosial perusahaan yang diarahkan pada upaya untuk memelihara hubungan baik dengan stakeholders. Contoh upaya seperti menjaga hubungan baik dengan karyawan, konsumen, pemasok, distributor atau perantara pemasaran, investor, masyarakat dan juga pemerintah. Pada perusahaan perbankan, hubungan baik dengan nasabah dapat dilakukan dengan Cara melayani nasabah dengan baik, ramah, profesional, dan memberikan informasi yang benar dan transparan. Dampak positif dari tanggung jawab sosial perusahaan pada stakeholder juga Akan dirasakan sendiri oleh perusahaan karena semua Akan berpengaruh terhadap kegiatan operasional perusahaan.

\section{CSR reputation}

Keterlibatan CSR yang dilakukan oleh perusahaan salah satu tujuannya yaitu meningkatkan CSR 
reputation. CSR reputation menggambarkan kesan yang tertanam dibenak konsumen bahwa suatu perusahaan tertentu memiliki tanggung jawab sosial yang besar. Perusahaan menginginkan masyarakat untuk sadar akan upaya-upaya tanggung jawab sosial yang dilakukan oleh perusahaan. Dengan memiliki CSR reputation yang baik di mata masyarakat akan dapat meningkatkan kepercayaan masyarakat pada perusahaan (Lee, 2016). CSR reputation muncul dari upaya-upaya perusahaan dalam menunjukkan kepeduliannya terhadap lingkungan, masyarakat dan pihak yang terkait dalam operasional perusahaan. Semakin baik reputasi CSR yang dimiliki oleh perusahaan, maka semakin besar kemungkinan konsumen untuk bersedia membeli produk-produk yang ditawarkan perusahaan tersebut. Dari semua upaya perusahaan dalam membangun CSR reputation, secara tidak langsung juga mempengaruhi loyalitas konsumen terhadap suatu produk karena konsumen sadar akan reputasi yang baik dari sisi CSR perusahaan tersebut.

\section{Perceived brand quality}

Perceived brand quality dapat didefinisikan sebagai persepsi pelanggan mengenai kualitas atau keunggulan suatu produk secara keseluruhan dari berbagai alternatif produk lain yang tersedia di pasar. Perceived brand quality tidak selalu dapat ditentukan secara objektif karena penilaian tentang apa yang penting bagi pelanggan yang terlibat dapat berbeda satu sama lain. Perceived brand quality merupakan salah satu komponen ekuitas merek yang tidak berwujud (Aaker, 2009). Perceived brand quality merupakan persepsi pelanggan mengenai kualitas suatu produk yang didapatkan oleh pengalaman pribadi ataupun pengalaman orang lain yang disampaikan ke suatu media ataupun secara langsung. Konsumen yang sudah mendapatkan pengalaman positif dari suatu produk berpotensi untuk dapat membayar lebih atau loyal pada suatu produk yang dirasa memiliki kualitas sangat baik. Dengan demikian, perusahaan juga harus berusaha untuk membangun persepsi baik dari produk yang ditawarkan ke konsumen dengan terus menjaga dan meningkatkan kualitasnya agar kualitas yang ditawarkan sesuai atau melebihi ekspektasi konsumen.

\section{Brand preference}

Liu et al. (2014) mengemukakan bahwa brand preference sangat identik dengan minat beli konsumen dan brand preference menjadi topik utama dalam penetapan strategi produk. Brand preference juga dapat dijadikan sebagai prediktor penting dari pembelian suatu produk dan banyak digunakan sebagai ukuran ekuitas merek. Brand preference merupakan preferensi yang dimiliki oleh konsumen untuk memilih suatu merek tertentu yang dipercaya dan diyakini baik diantara berbagai pilihan merek yang tersedia. Brand preference juga ditemukan sebagai prediktor perusahaan untuk meramalkan apa yang menjadi keinginan konsumen dan sebagai komponen ekuitas suatu produk. Perusahaan yang melakukan CSR sebagai salah satu bagian dari kegiatan operasionalnya berpeluang besar dipilih oleh konsumen karena alasan konsumen untuk membeli suatu produk tidak hanya didasarkan pada manfaat ekonomi namun juga manfaat non ekonomi misalnya untuk mendukung kegiatan CSR yang dilakukan perusahaan.

\section{CSR to environment, CSR to society, CSR to stakeholders dan brand preference}

Inisiatif perusahaan untuk menerapkan CSR dapat menjadi salah satu strategi untuk meningkatkan brand preference karena pada kenyataannya konsumen membeli suatu produk atau merek tertentu untuk alasan lain, bukan hanya untuk sekedar mencari manfaat ekonomi. Alasan tersebut misalnya alasan ingin mendukung kegiatan CSR yang dilakukan perusahaan, ingin berperan aktif dalam mendukung program go green, ingin berperan aktif dalam membantu masyarakat, dan sebagainya. CSR yang dilakukan perusahaan dapat dalam bentuk CSR to environment yang mencakup aktivitas tanggung 
jawab sosial perusahaan yang diarahkan pada upaya untuk melestarikan lingkungan, CSR to society yang mencakup aktivitas tanggung jawab sosial perusahaan yang diarahkan pada upaya untuk meningkatkan kesejahteraan masyarakat, dan CSR to stakeholders yang mencakup aktivitas tanggung jawab sosial perusahaan yang diarahkan pada upaya untuk memelihara hubungan baik dengan stakeholders. Penelitian terdahulu yang dilakukan oleh Liu et al. (2014) menemukan bahwa CSR to stakeholders, CSR to society, dan CSR to environment berpengaruh positif terhadap Brand Preference. Dengan demikian hipotesis yang diuji dalam penelitian ini adalah:

H1: CSR to environment mempengaruhi brand preference.

$\mathrm{H} 2$ : CSR to society mempengaruhi brand preference.

H3: CSR to stakeholder's mempengaruhi brand preference.

\section{CSR reputation dan brand preference}

Reputasi sebagai perusahaan yang bertanggung jawab sosial dapat menjadi aset tidak berwujud atau aset strategik bagi perusahaan dan mendorong pencapaian keunggulan kompetitif perusahaan di industri. Perusahaan yang memiliki reputasi sebagai perusahaan yang bertanggung jawab sosial Akan lebih dikenal oleh masyarakat luas dan kemungkinan konsumen untuk membeli produk yang ditawarkan oleh perusahaan tersebut lebih tinggi. Namun, penelitian terdahulu yang dilakukan oleh Chomvilailuk dan Butcher (2010) dan Mirabi et al. (2014) menemukan bahwa CSR reputation tidak berpengaruh terhadap brand preference. Berdasarkan hal tersebut, penelitian ini mengajukan hipotesis:

H4: CSR reputation mempengaruhi brand preference.

\section{Perceived brand quality dan brand preference}

Kualitas menjadi salah satu faktor yang mendorong individu untuk melakukan pembelian pada suatu produk atau merek tertentu. Individu lebih cenderung memilih untuk membeli produk atau merek yang menawarkan kualitas lebih bagus dengan kisaran harga yang sebanding. Oleh karenanya, perusahaan perlu mempertahankan dan meningkatkan kualitas dari produk yang ditawarkan ke konsumen. Penelitian sebelumnya yang dilakukan oleh Chomvilailuk dan Butcher (2010), Liu et al. (2014), dan Mirabi et al. (2014) yang menemukan bahwa perceived brand quality berpengaruh positif terhadap brand preference. Dengan demikian hipotesis yang diuji dalam penelitian ini adalah:

H5: Perceived brand quality mempengaruhi brand preference.

\section{Model Penelitian}

Model penelitian yang diuji dalam penelitian ini dapat dilihat pada Gambar 1.

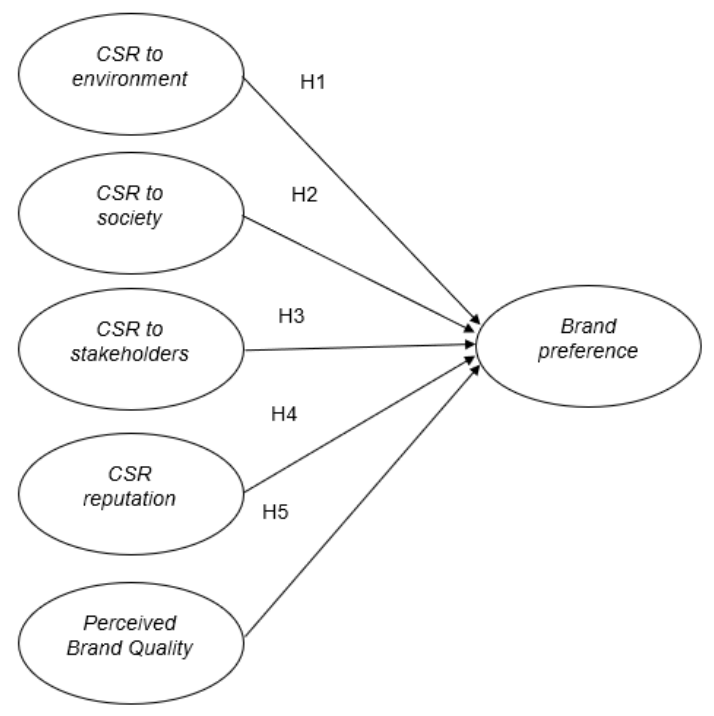

\section{Metode Penelitian}

\section{Waktu dan Tempat Penelitian}

Pengumpulan data penelitian ini dilakukan selama dua bulan yaitu pada bulan April sampai dengan Mei 2019. Pelaksanaan penelitian ini dilakukan di Bank BCA yang berlokasi di Jakarta Selatan dan Jakarta Pusat. Tujuan dipilihnya lokasi tersebut sebagai lokasi penelitian karena Bank BCA memiliki jumlah 61 Kantor Cabang Pembantu dan 10 Kantor Cabang Utama di Jakarta Selatan dan Jakarta Pusat (www.bca.co.id, 2018).

\section{Definisi Operasional Variabel}

Variabel independen yang diteliti dalam penelitian ini adalah CSR to environment, CSR to society, CSR to stakeholders, CSR reputation, and perceived brand quality. Sedangkan variabel dependen yang diteliti 
adalah brand preference. Instrumen penelitian yang digunakan dalam penelitian ini bersumber dari penelitian Liu et al. (2014) dan Chomvilailuk dan Butcher (2010). Skala yang digunakan adalah skala interval berupa skala likert 7 poin mulai dari 1 yang menyatakan sangat tidak setuju hingga 7 yang menyatakan sangat setuju.

\section{Populasi dan Sampel}

Populasi dari penelitian ini adalah semua nasabah Bank BCA yang berada di DKI Jakarta. Sedangkan sampel dari penelitian ini adalah nasabah Bank BCA yang berlokasi di Jakarta Selatan dan Jakarta Pusat yang mengetahui program CSR Bank BCA. Metode pengambilan sampel yang digunakan yaitu nonprobability sampling dengan teknik purposive dan snowball sampling. Kriteria yang digunakan untuk menentukan sampel adalah responden mengetahui program CSR yang dilakukan oleh Bank BCA. Jumlah responden yang diambil dalam penelitian ini adalah 173 responden. Jumlah ini sudah memenuhi kriteria minimal sampel menurut Hair et al. (2010) yang mensyaratkan jumlah sampel sebaiknya adalah 5-10 kali jumlah indikator.

\section{Alat Analisis Data}

Alat analisis data yang digunakan dalam penelitian ini adalah analisis regresi linier berganda dengan menggunakan software statistik SPSS. Uji asumsi klasik regresi yang mencakup uji multikolinieritas, uji heterokedastisitas, uji autokorelasi, dan uji normalitas dilakukan sebelum data diuji menggunakan regresi berganda.

\section{Hasil Analisis Data dan Pembahasan}

\section{Hasil Pretest}

Sebelum kuesioner didistribusikan ke sampel besar, peneliti melakukan pretest ke 30 responden terlebih dahulu untuk mengetahui validitas dan reliabilitas dari instrumen penelitian yang digunakan. Pretest mencakup uji validitas dan uji reliabilitas. Hasil uji validitas penelitian ini disajikan pada Tabel 1, sedangkan hasil uji reliabilitas dapat dilihat pada Tabel 2.

TABEL 1.

\section{HASIL UJI VALIDITAS}

\begin{tabular}{|l|l|l|l|l|}
\hline $\begin{array}{l}\text { Variab } \\
\text { el }\end{array}$ & Indikator & $\begin{array}{l}\text { Nilai } \\
\text { Korelasi } \\
\text { Pearson }\end{array}$ & Sig. & $\begin{array}{l}\text { Kesimp } \\
\text { ulan }\end{array}$ \\
\hline $\begin{array}{l}\text { CSR to } \\
\text { enviro } \\
\text { nment }\end{array}$ & $\begin{array}{l}\text { Perusahaan } \\
\text { mempromosika } \\
\mathrm{n} \mathrm{pelestarian} \\
\text { lingkungan } \\
\text { (env1) }\end{array}$ & 0,649 & 0,000 & Valid \\
\cline { 2 - 5 } & $\begin{array}{l}\text { Perusahaan } \\
\text { memiliki desain } \\
\text { bangunan yang } \\
\text { ramah } \\
\text { lingkungan } \\
\text { (env2) }\end{array}$ & 0,874 & 0,000 & Valid \\
\hline
\end{tabular}

\begin{tabular}{|c|c|c|c|c|}
\hline $\begin{array}{l}\text { Variab } \\
\text { el }\end{array}$ & Indikator & $\begin{array}{l}\text { Nilai } \\
\text { Korelasi } \\
\text { Pearson }\end{array}$ & Sig. & $\begin{array}{l}\text { Kesimp } \\
\text { ulan }\end{array}$ \\
\hline & $\begin{array}{l}\text { Perusahaan } \\
\text { menawarkan } \\
\text { program khusus } \\
\text { untuk } \\
\text { mengurangi } \\
\text { barang sekali } \\
\text { pakai (env3) }\end{array}$ & 0,828 & 0,000 & Valid \\
\hline & $\begin{array}{l}\text { Perusahaan } \\
\text { menawarkan } \\
\text { program khusus } \\
\text { untuk } \\
\text { meningkatkan } \\
\text { keamanan } \\
\text { public (env4) } \\
\end{array}$ & 0,700 & 0,000 & Valid \\
\hline & $\begin{array}{l}\text { Perusahaan } \\
\text { menawarkan } \\
\text { program khusus } \\
\text { untuk } \\
\text { menghemat } \\
\text { energi (env5) }\end{array}$ & 0,735 & 0,000 & Valid \\
\hline & $\begin{array}{l}\text { Perusahaan } \\
\text { menawarkan } \\
\text { program khusus } \\
\text { untuk } \\
\text { mengurangi } \\
\text { penggunaan air } \\
\text { (env6) } \\
\end{array}$ & 0,448 & 0,013 & Valid \\
\hline \multirow[t]{4}{*}{$\begin{array}{l}\text { CSR to } \\
\text { society }\end{array}$} & $\begin{array}{l}\text { Perusahaan } \\
\text { mendukung } \\
\text { organisasi non } \\
\text { pemerintah yang } \\
\text { membantu } \\
\text { masalah yang } \\
\text { terjadi di } \\
\text { masyarakat } \\
\text { (sct1) }\end{array}$ & 0,736 & 0,000 & Valid \\
\hline & $\begin{array}{l}\text { Perusahaan } \\
\text { berkontribusi } \\
\text { pada proyek } \\
\text { kesejahteraan } \\
\text { masyarakat } \\
\text { (sct2) }\end{array}$ & 0,725 & 0,000 & Valid \\
\hline & $\begin{array}{l}\text { Perusahaan } \\
\text { menciptakan } \\
\text { kehidupan yang } \\
\text { lebih baik bagi } \\
\text { generasi } \\
\text { mendatang } \\
\text { (sct3) }\end{array}$ & 0,651 & 0,000 & Valid \\
\hline & $\begin{array}{l}\text { Perusahaan } \\
\text { menargetkan } \\
\text { pertumbuhan } \\
\text { berkelanjutan } \\
\text { bagi generasi } \\
\text { mendatang } \\
\text { (sct4) }\end{array}$ & 0,594 & 0,001 & Valid \\
\hline CSR to & Perusahaan & 0,478 & 0,008 & Valid \\
\hline
\end{tabular}

175 | Jurnal Akuntansi, Ekonomi dan Manajemen Bisnis | Vol. 7 No.2, December 2019, 170-181 | E-ISSN: 2548-9836 


\begin{tabular}{|c|c|c|c|c|}
\hline $\begin{array}{l}\text { Variab } \\
\text { el }\end{array}$ & Indikator & $\begin{array}{l}\text { Nilai } \\
\text { Korelasi } \\
\text { Pearson }\end{array}$ & Sig. & $\begin{array}{l}\text { Kesimp } \\
\text { ulan }\end{array}$ \\
\hline \multirow[t]{6}{*}{$\begin{array}{l}\text { stakeh } \\
\text { olders }\end{array}$} & $\begin{array}{l}\text { menghormati } \\
\text { hak-hak } \\
\text { konsumen (stk1) }\end{array}$ & & & \\
\hline & $\begin{array}{l}\text { Perusahaan } \\
\text { menyediakan } \\
\text { informasi yang } \\
\text { lengkap bagi } \\
\text { konsumen (stk2) }\end{array}$ & 0,661 & 0,000 & Valid \\
\hline & $\begin{array}{l}\text { Perusahaan } \\
\text { mengutamakan } \\
\text { kepuasan } \\
\text { konsumen (stk3) }\end{array}$ & 0,656 & 0,000 & Valid \\
\hline & $\begin{array}{l}\text { Perusahaan } \\
\text { menyediakan } \\
\text { lingkungan } \\
\text { kerja yang aman } \\
\text { (stk4) }\end{array}$ & 0,786 & 0,000 & Valid \\
\hline & $\begin{array}{l}\text { Perusahaan } \\
\text { mematuhi } \\
\text { peraturan dan } \\
\text { hukum yang } \\
\text { berlaku (stk5) }\end{array}$ & 0,542 & 0,002 & Valid \\
\hline & $\begin{array}{l}\text { Perusahaan } \\
\text { menentang } \\
\text { praktek } \\
\text { pornografi, } \\
\text { perjudian, dan } \\
\text { narkoba (stk6) } \\
\end{array}$ & 0,640 & 0,000 & Valid \\
\hline \multirow[t]{6}{*}{$\begin{array}{l}\text { CSR } \\
\text { reputat } \\
\text { ion }\end{array}$} & $\begin{array}{l}\text { Sebagian besar } \\
\text { keuntungan } \\
\text { perusahaan } \\
\text { digunakan untuk } \\
\text { membantu } \\
\text { masyarakat } \\
\text { (rep1) }\end{array}$ & 0,592 & 0,001 & Valid \\
\hline & $\begin{array}{l}\text { Kode etik yang } \\
\text { dimiliki } \\
\text { perusahaan } \\
\text { melebihi } \\
\text { rata-rata (rep2) } \\
\end{array}$ & 0,899 & 0,000 & Valid \\
\hline & \begin{tabular}{lr}
\multicolumn{2}{l}{ Perusahaan } \\
memiliki \\
reputasi & CSR \\
yang & tinggi \\
(rep3) & \\
\end{tabular} & 0,797 & 0,000 & Valid \\
\hline & $\begin{array}{l}\text { Perusahaan } \\
\text { mendukung } \\
\text { pelestarian } \\
\text { lingkungan } \\
\text { (rep4) }\end{array}$ & 0,726 & 0,000 & Valid \\
\hline & $\begin{array}{l}\text { Perusahaan } \\
\text { mendukung } \\
\text { budaya } \\
\text { tradisional } \\
\text { Indonesia (rep5) } \\
\end{array}$ & 0,744 & 0,000 & Valid \\
\hline & $\begin{array}{l}\text { Perusahaan } \\
\text { banyak } \\
\text { mencurahkan } \\
\text { waktu untuk } \\
\text { membantu } \\
\text { masyarakat } \\
\text { (rep6) }\end{array}$ & 0,701 & 0,000 & Valid \\
\hline Percei & Penilaian baik & 0,733 & 0,000 & Valid \\
\hline
\end{tabular}

\begin{tabular}{|c|c|c|c|c|}
\hline $\begin{array}{l}\text { Variab } \\
\text { el }\end{array}$ & Indikator & $\begin{array}{l}\text { Nilai } \\
\text { Korelasi } \\
\text { Pearson }\end{array}$ & Sig. & $\begin{array}{l}\text { Kesimp } \\
\text { ulan }\end{array}$ \\
\hline \multirow[t]{4}{*}{$\begin{array}{l}\text { ved } \\
\text { brand } \\
\text { quality }\end{array}$} & $\begin{array}{l}\text { pada kualitas } \\
\text { layanan yang } \\
\text { diberikan } \\
\text { perusahaan } \\
\text { (pbq1) }\end{array}$ & & & \\
\hline & $\begin{array}{l}\text { Perusahaan } \\
\text { memiliki } \\
\text { kualitas layanan } \\
\text { terbaik di } \\
\text { industrinya } \\
\text { (pbq2) }\end{array}$ & 0,748 & 0,000 & Valid \\
\hline & $\begin{array}{l}\text { Perusahaan } \\
\text { memiliki } \\
\text { kualitas layanan } \\
\text { yang lebih baik } \\
\text { dibandingkan } \\
\text { pesaingnya } \\
\text { (pbq3) }\end{array}$ & 0,685 & 0,000 & Valid \\
\hline & $\begin{array}{l}\text { Perusahaan } \\
\text { memiliki } \\
\text { kualitas yang } \\
\text { baik dari sisi } \\
\text { kinerja (pbq4) }\end{array}$ & 0,755 & 0,000 & Valid \\
\hline \multirow[t]{5}{*}{$\begin{array}{l}\text { Brand } \\
\text { prefere } \\
\text { nce }\end{array}$} & $\begin{array}{l}\text { Selalu menjadi } \\
\text { pilihan utama } \\
\text { walaupun } \\
\text { perusahaan lain } \\
\text { menawarkan } \\
\text { layanan yang } \\
\text { lebih bagus } \\
\text { (pre1) }\end{array}$ & 0,651 & 0,000 & Valid \\
\hline & $\begin{array}{l}\text { Selalu menjadi } \\
\text { pilihan utama } \\
\text { walaupun } \\
\text { perusahaan lain } \\
\text { menawarkan } \\
\text { kualitas yang } \\
\text { lebih bagus } \\
\text { (pre2) }\end{array}$ & 0,568 & 0,001 & Valid \\
\hline & $\begin{array}{l}\text { Selalu menjadi } \\
\text { pilihan utama } \\
\text { walaupun } \\
\text { perusahaan lain } \\
\text { menawarkan } \\
\text { layanan yang } \\
\text { lebih nyaman } \\
\text { (pre3) }\end{array}$ & 0,700 & 0,000 & Valid \\
\hline & $\begin{array}{l}\text { Selalu menjadi } \\
\text { pilihan utama di } \\
\text { industri dimana } \\
\text { perusahaan } \\
\text { beroperasi } \\
\text { (pre4) }\end{array}$ & 0,714 & 0,000 & Valid \\
\hline & $\begin{array}{l}\text { Selalu memiliki } \\
\text { preferensi yang } \\
\text { kuat pada } \\
\text { perusahaan } \\
\text { (pre5) }\end{array}$ & 0,702 & 0,000 & Valid \\
\hline
\end{tabular}

Sumber: Data penelitian diolah (2019)

Hasil uji validitas pada Tabel 1 menunjukkan bahwa seluruh indikator pada penelitian ini telah valid 
karena memiliki nilai korelasi pearson > 0,4 dan tingkat signifikansi $<0,05$.

TABEL 2.

HASIL UJI RELIABILITAS

\begin{tabular}{|l|l|l|}
\hline Variabel & $\begin{array}{l}\text { Nilai } \\
\text { Cronbach } \\
\text { Alpha }\end{array}$ & Keterangan \\
\hline CSR to Environment & 0,811 & Reliabel \\
\hline CSR to Society & 0,603 & Reliabel \\
\hline CSR to Stakeholders & 0,723 & Reliabel \\
\hline CSR reputation & 0,839 & Reliabel \\
\hline $\begin{array}{l}\text { Perceived Brand } \\
\text { Quality }\end{array}$ & 0,695 & Reliabel \\
\hline Brand Preference & 0,689 & Reliabel \\
\hline
\end{tabular}

Sumber: Data penelitian diolah (2019)

Berdasarkan hasil uji reliabilitas pada Tabel 2 dapat disimpulkan bahwa seluruh variabel pada penelitian ini sudah reliabel karena memiliki nilai Cronbach Alpha $>0,6$.

\section{Profil Responden}

Profil responden dalam penelitian ini dapat dilihat pada tabel 3 .

TABEL 3.

PROFIL RESPONDEN

\begin{tabular}{|l|l|l|l|}
\hline Demografis Responden & Frekuensi & Presentase \\
\hline Jenis Kelamin & Pria & 110 & $63,6 \%$ \\
\cline { 2 - 4 } & Wanita & 63 & $36,4 \%$ \\
\hline Usia & $\begin{array}{l}18-24 \\
\text { Tahun }\end{array}$ & 165 & $95,4 \%$ \\
\cline { 2 - 4 } & $\begin{array}{l}25-34 \\
\text { Tahun }\end{array}$ & 6 & $3,5 \%$ \\
\cline { 2 - 4 } & $\begin{array}{l}35-44 \\
\text { Tahun }\end{array}$ & 2 & $1,2 \%$ \\
\hline Pendidikan & SMA & 116 & $67,1 \%$ \\
\cline { 2 - 4 } Terakhir & S1 & 57 & $32,9 \%$ \\
\hline Pekerjaan & Mahasiswa & 127 & $19,7 \%$ \\
\cline { 2 - 4 } & $\begin{array}{l}\text { Karyawan } \\
\text { Swasta }\end{array}$ & 34 & $6,9 \%$ \\
\cline { 2 - 4 } & Wirausaha & 12 & \\
\hline
\end{tabular}

Sumber: Data penelitian diolah (2019)

Berdasarkan Tabel 3 dapat dilihat bahwa responden pria lebih banyak dibandingkan dengan responden wanita dengan jumlah responden 173 orang yang berusia mayoritas berumur 18-24 tahun, pendidikan terakhir dari mayoritas responden yaitu SMA dan mayoritas pekerjaan dari responden adalah mahasiswa.

\section{Hasil Uji Asumsi Klasik Regresi}

Uji Multikolinearitas

Hasil uji multikolinearitas dalam penelitian ini dapat dilihat pada Tabel 4 .

TABEL 4

HASIL UJI MULTIKOLINEARITAS

\begin{tabular}{|c|c|c|c|c|c|c|c|}
\hline \multirow[b]{2}{*}{ Model } & \multicolumn{2}{|c|}{$\begin{array}{l}\text { Unstandardiz } \\
\text { ed } \\
\text { Coefficients }\end{array}$} & \multirow{2}{*}{$\begin{array}{c}\text { Standardized } \\
\text { Coefficients } \\
\text { Beta }\end{array}$} & \multirow[b]{2}{*}{$\mathrm{t}$} & \multirow[b]{2}{*}{ Sig. } & \multicolumn{2}{|c|}{$\begin{array}{c}\text { Collinearity } \\
\text { Statistics }\end{array}$} \\
\hline & B & $\begin{array}{l}\text { Std. } \\
\text { Error }\end{array}$ & & & & $\begin{array}{c}\text { Tolera } \\
\text { nce }\end{array}$ & VIF \\
\hline $\begin{array}{l}\text { 1(Consta } \\
\text { nt) }\end{array}$ & 3.103 & 6.379 & & .486 & .627 & & \\
\hline $\begin{array}{l}\text { totalen } \\
\mathrm{v}\end{array}$ & .215 & .071 & .182 & $\begin{array}{c}3.02 \\
1\end{array}$ & .003 & .821 & $\begin{array}{c}1.21 \\
8\end{array}$ \\
\hline totalsct & .492 & .180 & .154 & $\begin{array}{c}2.72 \\
8\end{array}$ & .007 & .938 & $\begin{array}{c}1.06 \\
6\end{array}$ \\
\hline totalstk & .212 & .077 & .206 & $\begin{array}{c}2.74 \\
6\end{array}$ & .007 & .530 & $\begin{array}{c}1.88 \\
7\end{array}$ \\
\hline totalrep & -.422 & .186 & -.133 & $\begin{array}{c}-2.26 \\
9\end{array}$ & .025 & .873 & $\begin{array}{c}1.14 \\
6\end{array}$ \\
\hline $\begin{array}{l}\text { totalpb } \\
\mathrm{q}\end{array}$ & .602 & .093 & .463 & $\begin{array}{c}6.50 \\
2\end{array}$ & .000 & .588 & $\begin{array}{c}1.70 \\
1\end{array}$ \\
\hline
\end{tabular}

Hasil uji multikolinearitas pada Tabel 4 menunjukkan bahwa nilai nilai Tolerance berada diatas 0,1 dan Variance Inflation Factor (VIF) tidak melebihi 10 yang artinya tidak terjadi multikolinearitas dalam model regresi.

\section{Uji Heterokedastisitas}

Hasil uji heterokedastisitas dalam penelitian ini dapat dilihat pada Gambar 2.

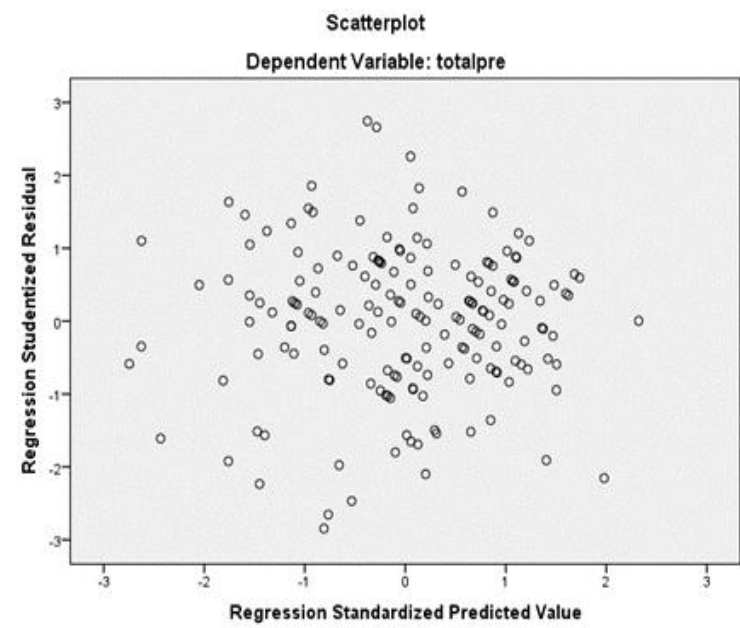

Gambar 2. Hasil Uji Heterokedastisitas

Sumber: Hasil Olah Data software IBM SPSS Statistics 23

Hasil uji Heterokedastisitas pada Gambar 2 menunjukkan bahwa titik-titik menyebar disekitar angka 0 pada sumbu Y dan tidak membentuk pola. Oleh sebab itu, dapat dikatakan tidak terjadi 
heterokedastisitas dalam model penelitian.

\section{Uji Autokorelasi}

Hasil uji autokorelasi dalam penelitian ini dapat dilihat pada Tabel 5 .

TABEL 5.

HASIL UJI AUTOKORELASI

\section{Hasil Uji Regresi Linier Berganda}

\section{Koefisien Determinasi}

Hasil uji koefisien determinasi dalam penelitian ini dapat dilihat pada Tabel 6.

TABEL 6

MODEL SUMMARY

\begin{tabular}{|c|c|c|c|c|c|c|c|c|c|c|c|}
\hline Model & $\mathrm{R}$ & R Square & $\begin{array}{l}\text { Adjusted R } \\
\text { Square }\end{array}$ & $\begin{array}{l}\text { Std. Error of } \\
\text { the Estimate }\end{array}$ & $\begin{array}{l}\text { Durbin- } \\
\text { Watson }\end{array}$ & \multicolumn{6}{|c|}{ Model Summary ${ }^{b}$} \\
\hline 1 & $.708^{\mathrm{a}}$ & .501 & .486 & 2.86735 & 1.81 & Model & $\mathrm{R}$ & R Square & $\begin{array}{l}\text { AdjustedR } \\
\text { Square }\end{array}$ & $\begin{array}{l}\text { Std. Error of } \\
\text { the Estimate }\end{array}$ & $\begin{array}{l}\text { Durbin- } \\
\text { Watson }\end{array}$ \\
\hline \multicolumn{6}{|c|}{ a. Predictors: (Constant), totalpbq, totalsct, totalenv, totalrep, totalstk } & 1 & $.708^{\mathrm{a}}$ & .501 & .486 & 2.86735 & 1.869 \\
\hline \multicolumn{6}{|c|}{ b. Dependent Variable: totalpre } & \multicolumn{6}{|c|}{ a. Predictors: (Constant), totalpbq, totalsct, totalenv, totalrep, totalstk } \\
\hline \multicolumn{6}{|c|}{ Sumber: Hasil Olah Data software IBM SPSS Statistics 23} & \multicolumn{6}{|c|}{ b. Dependent Variable: totalpre } \\
\hline
\end{tabular}

Sumber: Hasil Olah Data software IBM SPSS Statistics 23

Berdasarkan hasil uji autokorelasi pada Tabel 5 , nilai yang berada di rentang nilai tabel $(\mathrm{k}=5, \mathrm{n}=173)$ yaitu 1,811 - 2,189. Dengan hasil tersebut dapat disimpulkan tidak ada autokorelasi positif maupun negatif pada model regresi penelitian ini.

\section{Uji Normalitas}

Hasil uji normalitas dalam penelitian ini dapat dilihat pada Gambar 3.

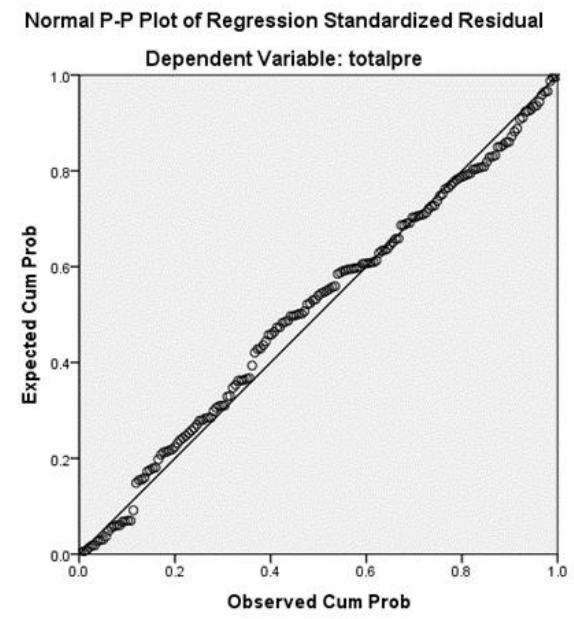

Gambar 3. Hasil Uji Normalitas

Sumber: Hasil Olah Data software IBM SPSS Statistics 23

Berdasarkan hasil uji normalitas pada Gambar 3 dapat dilihat bahwa titik-titik temu antara residual dengan nilai prediksi tidak menyimpang dan mengikuti garis normal. Dengan hasil tersebut, model penelitian ini memiliki data yang terdistribusi secara normal.

\section{Uji F}

Hasil uji $\mathrm{F}$ dalam penelitian ini dapat dilihat pada Tabel 7.

TABEL 7.

HASIL UJI F

\begin{tabular}{|c|c|c|c|c|c|c|}
\hline \multicolumn{7}{|c|}{ ANOVA $^{a}$} \\
\hline Model & & $\begin{array}{l}\text { Sum of } \\
\text { Squares }\end{array}$ & df & Mean Square & $\mathrm{F}$ & Sig. \\
\hline \multirow[t]{3}{*}{1} & Regression & 1380.836 & 5 & 276.167 & 33.590 & $.000^{\mathrm{b}}$ \\
\hline & Residual & 1373.025 & 167 & 8.222 & & \\
\hline & Total & 2753.861 & 172 & & & \\
\hline
\end{tabular}

a. Dependent Variable: totalpre

b. Predictors: (Constant), totalpbq, totalsct, totalenv, totalrep, totalstk

Sumber: Hasil Olah Data software IBM SPSS Statistics 23

Tabel 7 menunjukkan tingkat signifikansi yang dihasilkan adalah sebesar 0, 000 dengan nilai $\mathrm{F}$ sebesar 33, 590. Dengan demikian dapat disimpulkan bahwa CSR to environment, CSR to society, CSR to stakeholders, CSR reputation, perceived brand quality secara bersama-sama berpengaruh terhadap brand preference. 


\section{Uji t}

Hasil uji t dalam penelitian ini dapat dilihat pada Tabel 8.

TABEL 8.

HASIL UJI T

\begin{tabular}{|c|c|c|c|c|c|c|}
\hline & & \multicolumn{5}{|c|}{ Coefficients $^{a}$} \\
\hline \multirow[b]{2}{*}{ Mode } & & \multicolumn{2}{|c|}{ Unstandardized Coefficients } & \multirow{2}{*}{$\begin{array}{c}\text { Standardized } \\
\text { Coefficients }\end{array}$} & \multirow[b]{2}{*}{$\mathrm{t}$} & \multirow[b]{2}{*}{ Sig. } \\
\hline & & $B$ & Std. Error & & & \\
\hline \multirow[t]{6}{*}{1} & (Constant) & 3.103 & 6.379 & & .486 & .627 \\
\hline & totalenv & .215 & .071 & .182 & 3.021 & .003 \\
\hline & totalsct & .492 & .180 & .154 & 2.728 & .007 \\
\hline & totalstk & .212 & .077 & .206 & 2.746 & .007 \\
\hline & totaliep & -.422 & .186 & -133 & -2.269 & .025 \\
\hline & totalpbq & .602 & .093 & .463 & 6.502 & .000 \\
\hline
\end{tabular}

Sumber: Hasil Olah Data software IBM SPSS Statistics 23

Tabel 8 menunjukkan bahwa nilai signifikansi untuk variabel CSR to environment, CSR to society, CSR to stakeholders, CSR reputation, perceived brand quality kurang dari 0, 05. Dengan demikian semua variabel independen yang diteliti yaitu CSR to environment, CSR to society, CSR to stakeholders, CSR reputation dan perceived brand quality berpengaruh signifikan terhadap brand preference. Variabel yang paling berpengaruh kuat terhadap brand preference adalah perceived brand quality dengan nilai standardized coefficients beta sebesar 0,463. Kemudian diikuti oleh variabel CSR to stakeholders dengan nilai standardized coefficients beta sebesar 0,206; variabel CSR to environment dengan nilai standardized coefficients beta sebesar 0,182; dan CSR to society dengan nilai standardized coefficients beta sebesar 0,154. Variabel CSR reputation ditemukan berpengaruh signifikan namun negatif terhadap brand preference. Nilai negatif pada CSR reputation menunjukan bahwa semakin baik CSR reputation yang dimiliki perusahaan maka semakin rendah brand preference.

Model persamaan regresi yang dihasilkan dari penelitian ini adalah:

$\begin{aligned} \text { Brand preference = } & 3,103+0,215 \quad \text { CSR to } \\ & \text { environment }+0,492 \text { CSR to } \\ & \text { society }+0,212 \text { CSR to } \\ & \text { stakeholders }-0,422 \quad \text { CSR } \\ & \text { reputation }+0,602 \text { perceived } \\ & \text { brand quality }\end{aligned}$

\section{Pembahasan}

Penelitian ini menemukan beberapa temuan yang menarik. Pertama, CSR to environment, CSR to society dan CSR to stakeholders ditemukan berpengaruh terhadap brand preference. Temuan penelitian ini sejalan dengan penelitian terdahulu yang dilakukan oleh Liu et al. (2014). Hasil temuan penelitian ini menunjukkan bahwa pada konteks perusahaan perbankan di Indonesia, tipe CSR initiatives yang mempengaruhi pembentukan brand preference adalah CSR to environment, CSR to society dan CSR to stakeholders. CSR to stakeholders memiliki pengaruh paling kuat pada pembentukan brand preference dibandingkan dengan CSR to environment dan CSR to society. Dengan demikian, untuk membentuk brand preference, perusahaan perbankan seharusnya lebih fokus pada penerapan aktivitas tanggung jawab sosial perusahaan yang diarahkan pada upaya untuk memelihara hubungan baik dengan stakeholders.

Kedua, penelitian ini menemukan perceived brand quality berpengaruh terhadap brand preference. Temuan ini mendukung temuan penelitian sebelumnya yang dilakukan oleh Liu et al. (2014), Chomvilailuk dan Butcher (2010), dan Mirabi et al. (2014). Temuan penelitian ini menunjukkan bahwa pada konteks perusahaan perbankan di Indonesia, perceived brand quality memiliki pengaruh yang lebih kuat pada pembentukan brand preference dibandingkan dengan CSR initiatives. Artinya, pada konteks perusahaan perbankan di Indonesia, preferensi nasabah terhadap suatu bank lebih ditentukan oleh faktor kualitas baik kualitas produk maupun kualitas layanan yang diberikan oleh bank daripada aktivitas tanggung jawab sosial yang dilakukan oleh bank.

Ketiga, penelitian ini menemukan bahwa CSR reputation berpengaruh terhadap brand preference. Temuan penelitian ini berbeda dengan penelitian sebelumnya yang dilakukan oleh Chomvilailuk dan Butcher (2010) serta Mirabi et al. (2014) yang menemukan bahwa CSR reputation tidak berpengaruh terhadap brand preference. Berdasarkan analisis data yang telah dilakukan, penelitian ini menemukan bahwa CSR reputation berpengaruh negatif terhadap brand preference. Dengan kata lain, semakin bagus reputasi tanggung jawab sosial perusahaan maka semakin tidak mampu mendorong pembentukan preferensi merek nasabah pada perusahaan. Hal ini dapat disebabkan karena mayoritas responden dalam penelitian ini adalah nasabah berusia 18-24 tahun yang masuk dalam kelompok generasi milenial yang cenderung skeptis pada upaya CSR yang dilakukan perusahaan. Reputasi sebagai perusahaan yang bertanggung jawab sosial dinilai oleh nasabah milenial sebagai bentuk upaya mencari perhatian oleh perusahaan perbankan agar terkesan menunjukkan niat baik kepada masyarakat dan lingkungan serta 
hanya sekedar untuk memenuhi regulasi yang berlaku dan tidak didasarkan pada niat yang altruis untuk membantu meningkatkan kesejahteraan masyarakat dan mengatasi masalah lingkungan. Karena itu, untuk meminimalkan kesan seperti ini, perusahaan perbankan sebaiknya tidak terlalu berlebihan dalam menerapkan CSR.

\section{Kesimpulan dan Saran}

\section{Kesimpulan}

Kesimpulan yang dihasilkan dari penelitian ini adalah dalam konteks perusahaan perbankan di Indonesia, CSR to environment, CSR to society, CSR to stakeholders, CSR reputation dan perceived brand quality berpengaruh terhadap brand preference. Perceived brand quality memiliki pengaruh positif paling kuat terhadap brand preference dibandingkan dengan CSR to stakeholders, CSR to environment, dan CSR to society. CSR reputation ditemukan memiliki pengaruh negatif terhadap brand preference.

\section{Saran}

Berdasarkan hasil temuan penelitian, peneliti memberikan saran bagi perusahaan untuk meningkatkan perceived brand quality dengan terus melakukan inovasi dan menjadi pioneer di industri perbankan dalam hal penerapan teknologi perbankan. Selain inovasi, perusahaan juga harus terus meningkatkan kualitas produk dan kualitas layanan yang diberikan kepada nasabah. Disamping itu, perusahaan perbankan juga dapat terus menerapkan CSR dalam porsi yang wajar dan tidak berlebihan. Perusahaan perbankan dapat mengajak nasabah untuk terlibat aktif dalam CSR misalnya melalui kegiatan cause-related marketing atau mengajak nasabah untuk terjun secara langsung ke lapangan melakukan CSR sehingga penilaian negatif terhadap reputasi CSR dapat diminimalkan.

Saran yang dapat diberikan untuk penelitian mendatang adalah menguji CSR reputation sebagai variabel mediasi pada pengaruh CSR to environment, CSR to society, CSR to stakeholder's terhadap brand preference. Penelitian mendatang juga dapat menguji variabel perceived brand quality sebagai variabel mediasi pada pengaruh CSR to environment, CSR to society, CSR to stakeholders, dan CSR reputation terhadap brand preference. Penelitian selanjutnya sebaiknya juga menggunakan objek penelitian perusahaan perbankan lain atau perusahaan lain selain perbankan, menambah jumlah responden, dan memperluas cakupan penelitian tidak hanya di DKI Jakarta namun di kota-kota besar lainnya.

\section{Daftar Pustaka}

Aaker, D. A. 2009. Managing Brand Equity. New York: Simon \& Schuster.

Bank BCA. 2019. Laporan Tahunan Bank BCA 2018.

Diakses tanggal 19 Mei 2019, https://www.bca.co.id/ /media/Files/Report/

Tahunan/20190313-ar-bca-ina.ashx.

Bank BCA. 2019. Tanggung Jawab Sosial Perusahaan.

Diakses tanggal 19 Mei 2019, https://www.bca.co.id/tentang-bca/korporasi $/ \mathrm{csr}$

Chomvilailuk, R. \& Butcher, K. 2010. Enhancing brand preference through corporate social responsibility initiatives in Thai banking sector, Asia Pacific Journal of Marketing and Logistics, 22(3), 397-418.

Hair, J. F, Black, W. C, Babin, B. J., \& Anderson, R. E. 2006. Multivariate Data Analysis. 7th Edition. New Jersey: Pearson.

Lee, S. Y. 2016. How can companies succeed in forming CSR reputation? Corporate Communications: An International Journal, 21(4), 435-449.

Liu, M. T., Wong, I. A., Shi, G., Chu, R. \& Brock, J. L. 2014. The impact of corporate social responsibility (CSR) performance and perceived brand quality on customer-based brand preference, Journal of Services Marketing, 28(3), 181-194.

Mirabi, V. R., Asgari, A., Tehrani, A. G. \& Moghaddam, B. H. 2014. The Impact of Corporate Social Responsibility (CSR) on the Brand Preference In Banking Industry-The Case Study: Banks of Mellat and Refah in Iran), Kuwait Chapter of Arabian Journal of Business and Management Review, 3(7), 476-487.

Rahayu, E. M. 2018. BCA Dinobatkan Bank Terbaik oleh Euromoney Awards for Excellence 2018. Diakses tanggal 25 Maret 2019, https://swa.co.id/swa/trends/bca-dinobatkanbank-terbaik-oleh-euromoney-awards-for-ex cellence-2018.

Sen, S \& Bhattacharya, C. B. 2001. Does Doing Good 
Always Lead to Doing Better? Consumer

Reactions to Corporate Social Responsibility, Journal of Marketing Research, 38(2), 225-243.

Sen, S., Bhattacharya, C. B. \& Korschun, D. 2006. The role of corporate social responsibility in strengthening multiple stakeholder relationships: a field experiment, Journal of the Academy of Marketing Science, 34(2), 158-166.

Setiyaningrum, A. \& Aryanto, V. D. W. 2016. Corporate Ethics and Corporate Social Responsibility in Reinforcing Consumers Bonding: An Empirical Study in Controversial Industry, International Journal of Technoethics, 7(1), 1 - 15.

Peloza, J., \& Shang, J. 2010. How can corporate social responsibility activities create value for stakeholders? A systematic review, Journal of the Academy of Marketing Science, 39(1), 117-135.

Polonsky, M. J. \& Jevons, C. 2006. Understanding issue complexity when building a socially responsible brand, European Business Review, 18(5), 340-349. 